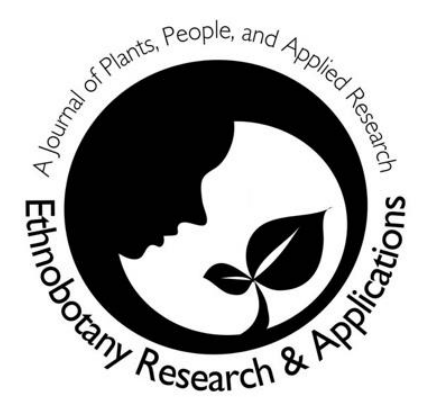

\title{
Wild edible fruits generate substantial income for local people of the Gunung Leuser National Park, Aceh Tamiang Region
}

\author{
Adi Bejo Suwardi, Zidni IIman Navia, Tisna Harmawan, \\ Syamsuardi, Erizal Mukhtar
}

\section{Research}

\begin{abstract}
Background: Gunung Leuser National Park offers a variety of wild edible fruit species (WEFs) with food, nutrition, medicine, and economic value to the local people. In recent times, these WEFs have been threatened by over-exploitation, land-use changes, and biodiversity loss. This study aims to investigate the diversity of WEFs and their contribution to household income for communities living around the National Park.
\end{abstract}

Methods: The study was conducted in three subdistricts adjacent to Gunung Leuser National Park. The plant materials were randomly collected from three sub-districts, while local knowledge was gathered through a structured survey and in-depth interviews. The informant sample comprised 450 people, 150 from each of the three sub-districts.

Results: A total of 54 wild edible fruit plants belonging to 41 genera and 27 families were recorded in the study area. Thirty-nine $(72.22 \%)$ species were found growing in forests, 12 (22.22\%) species in farmland, and $3(5.56 \%)$ species occur in the bush. Several species have economic value including Baccaurea macrophylla (Müll.Arg.) Müll.Arg., Baccaurea polyneura Hook.f., Diospyros kaki L.f., Flacourtia rukam Zoll.\&Moritzi, Garcinia atroviridis Griff. ex T.Anderson, Garcinia xanthochymus Hook.f. ex T.Anderson, Lansium domesticum Corrêa, Mangifera foetida Lour., Mangifera odorata Griff., Mangifera laurina Blume, Nephelium cuspidatum Blume, Passiflora edulis Sims., Pometia pinnata J.R. Forst. \& G. Forst., Syzygium aqueum (Burm. f.) Alston, and Syzygium malaccense (L.) Merr. \& L.M. Perry. These fruits formed a source of household income and were harvested by approximately $82 \%$ of respondents. The sale of WEFs contributed approximately $34.31 \%$ of the total annual household income. These findings confirm the assumption that WEFs are important for the generation of household income.

Conclusion: This study demonstrates the importance of WEFs to local communities in Aceh Tamiang, Indonesia, particularly rural communities living near Gunung Palung National Park. WEFs play an important role in rural livelihoods by ensuring food, medicine, and sustained income. Policies and legislation involving stakeholders are required to ensure the cultivation, management, sustainable use, and promotion of WEFs in order to encourage the economic growth of the rural community in the Aceh Tamiang region.

\section{Correspondence}

Adi Bejo Suwardi ${ }^{*}$, Zidni Ilman Navia ${ }^{2}$, Tisna Harmawan $^{3}$, Syamsuardi ${ }^{4}$, Erizal Mukhtar ${ }^{4}$

${ }^{1}$ Department of Biology Education, Faculty of Teacher Training and Education, Samudra University, Langsa, Aceh, 24416, Indonesia

${ }^{2}$ Department of Biology, Faculty of Engineering, Samudra University, Langsa, Aceh, 24416, Indonesia

${ }^{3}$ Department of Chemistry, Faculty of Engineering, Samudra University, Langsa, Aceh, 24416, Indonesia

${ }^{4}$ Department of Biology, Faculty of Mathematics and Sciences, Andalas University, Kampus Limau Manis Padang, 25163, West Sumatra, Indonesia

*Corresponding Author: adi.mipa@gmail.com

Ethnobotany Research \& Applications 20:11 (2020)

Key words: Aceh Tamiang district, biodiversity, economics, household, value addition 


\section{ABSTRAK}

Pendahuluan: Taman nasional Gunung Leuser memiliki berbagai jenis tumbuhan buah edible liar yang dimanfaatkan oleh masyarakat pedesaan, terutama sebagai sumber pangan, nutrisi, obatobatan, dan dapat menjadi sumber pendapatan keluarga. Saat initumbuhan buah liar terancam oleh eksploitasi berlebihan, perubahan penggunaan lahan, dan kehilangan keanekaragaman jenis. Penelitian ini bertujuan untuk menginvestigasi keanekaragaman jenis tumbuhan buah edibel liar dan kontribusinya terhadap pendapatan keluarga bagi masyarakat yang tinggal di sekitar Taman Nasional Gunung Leuser.

Metode: Penelitian dilakukan pada tiga Kecamatan yang berbatasan langsung dengan Taman Nasional Gunung Leuser. Sampel tumbuhan dikumpulkan secara acak dari tiga kecamatan, sementara itu, pengetahuan masyarakat dinilai dengan survey dan wawancara. Data diambil dengan melibatkan 450 orang dengan masing-masing 150 orang di setiap kecamatan.

Hasil: Sebanyak 54 jenis tumbuhan buah edible liar yang terdiri dari 41 marga dan 27 keluarga telah ditemukan selama penelitian. Sebanyak 39 (72.22 $\%)$ jenis ditemukan di hutan, $12(22,22 \%)$ jenis di kebun, dan $3(5,56 \%)$ jenis ditemukan di semak belukar. Beberapa jenis yang memiliki nilai ekonomi diantaranya Baccaurea macrophylla (Müll.Arg.) Müll.Arg., Baccaurea polyneura Hook.f., Diospyros kaki L.f., Flacourtia rukam Zoll.\&Moritzi, Garcinia atroviridis Griff. ex T.Anderson, Garcinia xanthochymus Hook.f. ex T.Anderson, Lansium domesticum Corrêa, Mangifera foetida Lour., Mangifera odorata Griff., Mangifera laurina Blume, Nephelium cuspidatum Blume, Passiflora edulis Sims., Pometia pinnata J.R. Forst. \& G. Forst., Syzygium aqueum (Burm. f.) Alston, and Syzygium malaccense (L.) Merr. \& L.M. Perry. Tumbuhan tersebut menjadi sumber pendapatan keluarga dan dipanen oleh sekitar $82 \%$ responden. Penjulan tumbuhan tersebut berkontribusi sebesar $34,31 \%$ terhadap total pendapatan tahunan keluarga. Hasil penelitian ini mengasumsikan bahwa tumbuhan buah edible liar ini sangat penting dalam mendukung ekonomi keluarga.

Kesimpulan: Penelitian ini menunjukkan tingkat kepentingan tumbuhan buah edible liar bagi masyarakat di Aceh Tamiang, Indonesia, terutama yang tinggal di sekitar Taman Nasional Gunung Leuser. Tumbuhan buah edible liar berperan penting dalam mendukung kehidupan masyarakat pedesaan sebagai sumber pangan, nutrisi, obat-obatan dan penghasilan keluarga. Kebijakan dan peraturan yang melibatkan semua pemangku kepentingan diperlukan untuk mendukung budidaya, manajemen, pemanfaatan berkelanjutan, dan promosi WEFs dalam rangka mendorong pertumbuhan ekonomi masyarakat pedesaan di wilayah Aceh Tamiang.

\section{Background}

Wild edible fruit plants (WEFs) refer to fruit plants growing in the natural habitat (Shava 2005). Wild plants form an important part of the human diet; almost 75,000 plant species are known to be edible (Diamond 2002; Leonti et al. 2006). These plants are generally grown in different habitats such as forests, cultivable fields, and even anthropogenically disturbed areas such as roadsides and wastelands (Beluhan \& Ranogajec 2010). WEFs have played a significant role in the livelihoods of rural communities in developing countries (Mwema et al. 2012; Mabaya et al. 2014; Khruomo \& Deb 2018) due to their nutritional and medicinal value (Biswas et al. 2018). WEFs provide vitamins and minerals that are essential for the maintenance of human health (Saka \& Msonthi 1994; Navia et al. 2015; Suwardi et al. 2018). Many WEFs contain more vitamin $C$ than the commercial species and are capable of providing macro and micronutrients in the diet (Bvenura \& Sivakumar 2007). They also provide a similar taste, flavor, and aroma as cultivated fruit plants (Suwardi et al. 2019a). In addition, WEFs are also important sources of traditional beverages, food recipes, oil, medicines, fodder, firewood, and building materials for rural communities (Maghembe et al. 1998; Suwardi et al. 2019b; Navia et al. 2020; Suwardi et al. 2020a). Local communities are known to possess extensive knowledge about the use of local plants as food and for other purposes (Sundriyal et al. 1998). Local people should enjoy continuous access to their natural habitats so that they maintain and improve their knowledge on the collection and preparation of food from wild edible plant resources (Somnasang \& MorenoBlack 2000).

Gunung Leuser National Park (GLNP), one of the world heritage sites was considered to be a hot spot of tropical fruit plants in Sumatra. Approximately 4,000 species of flora are found in this area (Wiratno et al. 2004). More than one million people live around the GLNP (Wiratno et al. 2004), and rely on forest resources for income and livelihood security. Fruits as one of the non-timber forest products offer potential to enhance the economic conditions of local communities (Deb et al. 2013). Oryema et al. (2013) reported that several WEFs have been identified as being consumed in large quantities, while also significantly contributing to the livelihoods of the local community in Gulu District, Uganda. For the local people in Riau Province, Indonesia, sales of WEFs accounted for $38 \%$ of the total annual family income 
(Pardede et al. 2018). Similarly, the communities in Central Aceh, Indonesia and the Eastern Nuba Mountains of Sudan obtained $43 \%$ and $0-100 \%$ of the total annual family income from sold WEFs (Salih-Kamal \& Ali, 2014; Navia et al., 2020). WEFs are therefore considered vital to sustaining rural livelihoods, reduce rural poverty, and promote rural economic growth (Maske et al. 2011; Ahenkan \& Boon 2011). Underutilization, high population growth, and land-use changes including the expansion of agricultural sector leading to deforestation have also to lead to loss of diversity of the WEFs (Ohiokpehai 2003; Bagra et al. 2006; Navia et al. 2020; Suwardi et al. 2020b), even in GLNP. WCS (2019) reported that about 4,685 ha of GLNP forests had been converted to agricultural land between 2000 and 2017, which also drove biodiversity loss. Loss of various species, in particular WEFs, will lead to increased food insecurity (Lulekal et al. 2011; Addis et al. 2013). Therefore, this study aims to investigate the diversity of WEFs and their contribution to household income for communities living around Gunung Leuser National Park, Aceh Tamiang Region.

\section{Materials and methods}

\section{Study area}

The study was conducted in three sub-districts of Aceh Tamiang districts $\left(03^{\circ} 53^{\prime} \mathrm{N}, 97^{\circ} 43^{\prime} \mathrm{E}, 700 \mathrm{~m}\right.$ a.s.l.), Aceh province, Indonesia including Tenggulun, Tamiang Hulu, and Bandar Pusaka as shown in Figure 1. These areas are typically forested and part of the buffer zone of the Gunung Leuser National Park. These areas have a tropical humid climate with a dry season mainly occurring from January to June, while the rainy season lasts from July to December. The rainfall ranges between 406 and $2,886 \mathrm{~mm}$ per year with 20 - 158 rainy days and the average temperature is around $260-300 \mathrm{C}$. The topography is generally mountainous and the zone is characterized by a cropping system (The Central Bureau of Statistics of Aceh Tamiang Regency, 2019).

\section{Data collection}

The present investigation of WEFs was based on an extensive field survey carried out from April to September 2018. Information on WEFs was obtained through participatory observations. The study involved a total of 450 respondents (150 individuals from each sub-district), who were selected through simple random sampling, with different background characteristics such as sex, age group, religion, marital status, tribe, and local language (Table 1). A questionnaire was prepared with four sections, namely: background characteristics of the respondents, collections and harvestings, sales, and other values of WEFs (Appendix 1). The questionnaire also included the amount of fruit harvested per year and income secured from fruit sales. The interview was conducted face to face in the Indonesian language and each interview lasted between 30 and 60 minutes.

Table 1. Demographic characteristics of respondents

\begin{tabular}{|c|c|c|c|}
\hline \multicolumn{2}{|c|}{ Baseline Characteristics } & $\begin{array}{c}\text { Number } \\
\text { (Total = } \\
450)\end{array}$ & Percentage \\
\hline \multirow[t]{2}{*}{ Gender } & Male & 214 & 47.56 \\
\hline & Female & 236 & 52.44 \\
\hline \multirow[t]{5}{*}{ Age } & $20-30$ & 96 & 21.33 \\
\hline & $31-40$ & 148 & 32.89 \\
\hline & $41-50$ & 122 & 27.11 \\
\hline & $51-60$ & 64 & 14.22 \\
\hline & $>60$ & 20 & 4.44 \\
\hline Religion & Islam & 450 & 100 \\
\hline \multirow[t]{3}{*}{ Marital status } & Single & 32 & 6.22 \\
\hline & Married & 406 & 91.11 \\
\hline & Widowed & 12 & 2.67 \\
\hline \multirow[t]{3}{*}{ Tribe } & Acehnese & 96 & 21.33 \\
\hline & Tamiang & 235 & 52.22 \\
\hline & Javanese & 119 & 26.44 \\
\hline \multirow[t]{3}{*}{ Local language } & Acehnese & 96 & 21.33 \\
\hline & Malay & 235 & 52.22 \\
\hline & Javanese & 119 & 26.44 \\
\hline
\end{tabular}

\section{Data analysis}

The contribution of WEFs to household income was estimated as a percentage of the total annual household income generated by WEFs sales. Computations were made in Microsoft Office Excel 2016. 


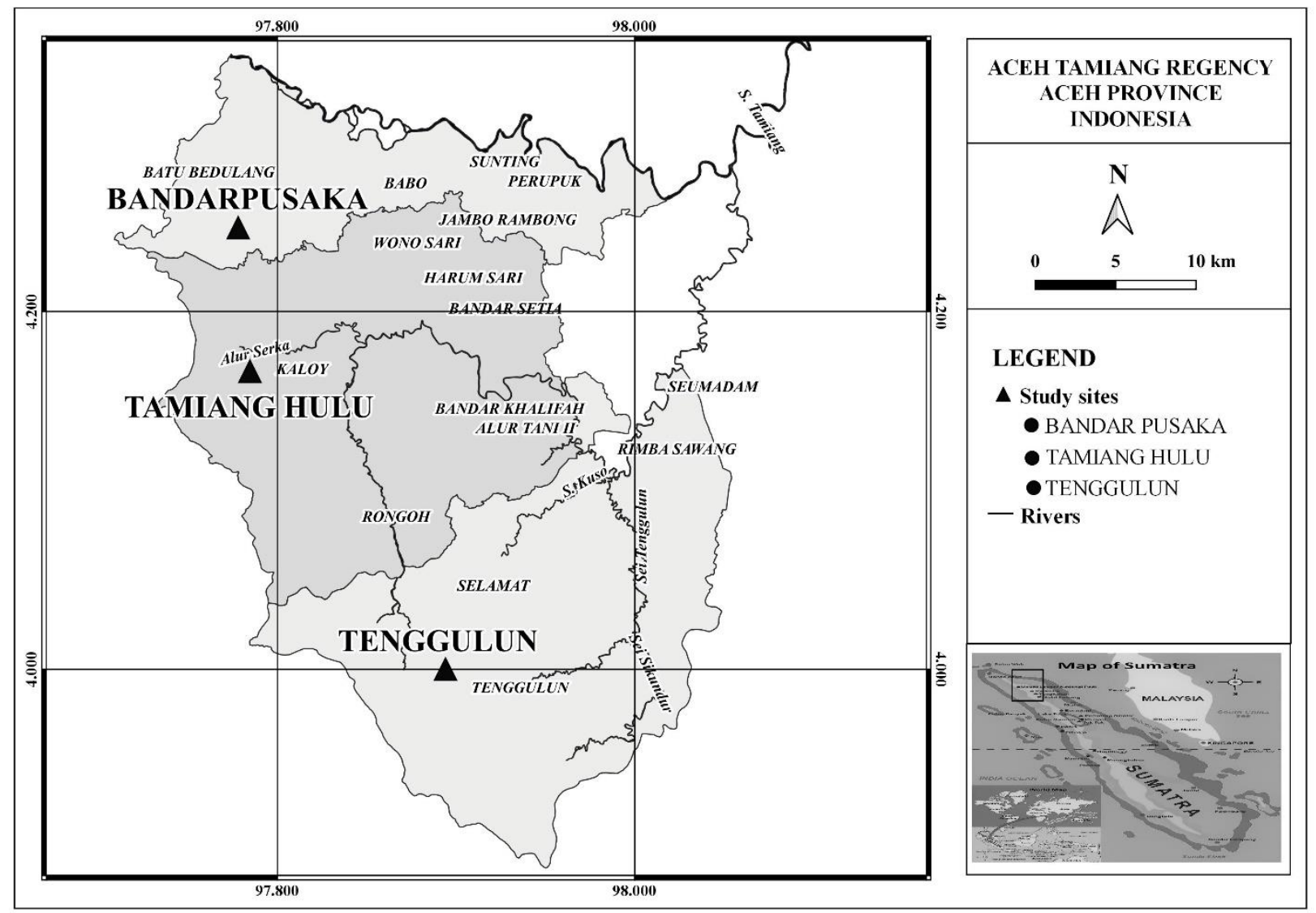

Figure 1. Map of Aceh Tamiang district showing the three study areas, Bandar Pusaka, Tamiang Hulu and Tenggulun sub-districts

\section{Results}

A total of 54 wild edible fruit plants, consisting of 41 genera and 27 families, were identified in the study area. Sapindaceae was the largest family contributing six species, followed by Meliaceae ( 5 species), Clusiaceae (4 species), and Myrtaceae (4 species). Anacardiaceae, Fagaceae, Malvaceae, and Phyllantaceae contributed three species each (Table 2).

Thirty-nine (72.22\%) species were found growing in forests, $12(22.22 \%)$ species in farmland, and 3 $(5.56 \%)$ species occurred in the bush. The mean number of WEFs identified by each age group of respondents ranged from 15.8 \pm 2.05 (20-30 years) to $50.31 \pm 3.22$ (41-50 years). Several WEFs have been recognized for all ages including Langsat (Lansium domesticum Corrêa), Kuwini (Mangifera odorata Griff.), Macang (Mangifera foetida Lour.), Asam pauh (Mangifera laurina Blume), Tampoi (Baccaurea macrophylla (Müll.Arg.) Müll.Arg.), Jentik (Baccaurea polyneura Hook.f.), Ceri (Prunus beccarii (Ridley) Kalkman), Jambu air (Syzygium garciniifolium (King) Merr. \& L.M.Perry), Jambu bol (Syzygium malaccense (L.) Merr. \& L.M. Perry), Asam kandis (Garcinia xanthochymus Hook.f. ex T.Anderson) and Asam gelugur (Garcinia atroviridis Griff. ex T.Anderson). While Durian enggang (Durio griffithii (Mast.) Bakh.), Jengkol hutan (Archidendron borneense I.C. Nielsen), Rambutan hutan (Nephelium juglandifolium Blume), and Peralih (Garcinia nigrolineata Planch. ex T.Anderson) are several examples for such less known species.

The respondents explained that the harvesting of WEFs is carried out mostly by men compared to women. Several of the WEFs such as Baccaurea macrophylla, B. polyneura, Diospyros kaki, Flacourtia rukam, Garcinia atroviridis, G. xanthochymus, Lansium domesticum, Mangifera foetida, $M$. odorata, M. laurina, Nephelium cuspidatum, Passiflora edulis, Pometia pinnata, Syzygium malaccense, and $S$. aqueum were harvested by $82 \%$ of the respondents. The majority of respondents collected between 10 to $200 \mathrm{~kg}$ of WEFs for sale or consumption by themselves. $L$. domesticum and $M$. foetida were found to be harvested in large quantities (more than $100 \mathrm{~kg}$ ). Approximately $40 \%$ of respondents reported that they only harvested small quantities of WEFs such as Castanopsis costata (Blume) A.DC, Eleiodoxa conferta (Griff.) Burret., and Garcinia nigrolineata Planch. ex T. Anders.

\section{Value addition}

According to the local people, a total of 15 species have additional values and are utilized as medicines, additive, juice, pickles, chutney, and in dried forms (Table 3). 
Most fruits were consumed raw and fresh, but several were consumed as pickles ( $M$. foetida, $M$. odorata, M. laurina, S. aqueum, S. garciniifolium, and $S$. malaccense), chutney (M. foetida, M. odorata, and $M$. laurina), or as an additive (G. atroviridis, $G$. xanthochymus, and Syzygium polyanthum (Wight) Walp). Few species were processed into juice ( $M$. foetida, $M$. odorata, and $M$. laurina). In addition, $B$. macrophylla is used as traditional medicine for the treatment of ringworm, while Santiria laevigata Blume, and Momordica balsamina L. are used in the treatment of diarrhea.

\section{Contribution of WEFs to household income}

Local communities in the study area collect WEFs for sale in the traditional market, roadsides, or neighborhood. Species, traded part, average quantity, and the market price of WEFs that were sold by local communities in the study area are shown in Table 4. Approximately $85.5 \%$ of respondents sold WEFs. Trading of WEFs were dominated by women compared to men. The highest quantity of fruits sold were M. foetida $(200 \pm 12.24$ $\mathrm{kg}$ ), and L. parasiticum (200 $\pm 10.54 \mathrm{~kg})$, followed by M. odorata $(160 \pm 2.82 \mathrm{~kg})$, S. malaccense (100 \pm $12.37 \mathrm{~kg}), S$. aqueum $(100 \pm 13.65 \mathrm{~kg})$, and $D$. kaki $(60 \pm 4.21 \mathrm{~kg})$. Several WEFs such as $L$. domesticum, N. cuspidatum, and M. foetida are sold in traditional markets or promoted on the roadside by local people. Among fruit species, M. foetida and $M$. odorata have high market price of around IDR 15,000-20,000 per $\mathrm{kg}$, followed by $L$. domesticum (IDR 12,0000-15,000), D. kaki, G. atroviridis (IDR $10,000-12,000 \mathrm{~kg}-1$ ), and $P$. edulis (IDR 10,000 kg$1)$. The mean income earned through the selling of WEFs by the households is IDR $13,220,000$ per year, with the mean income of each respondent being IDR 1,101,667 per month. Of all households selling WEFs, 68\% earned less than 25,000,000 Indonesian Rupiah (IDR) annually, while $32 \%$ earned more than $25,000,000$ IDR. The mean total annual contribution to the household income from selling of WEFs was around $34.41 \%$.

Table 2. Wild edible fruits in the study area

\begin{tabular}{|c|c|c|c|c|c|}
\hline Scientific Name & Family & Local Name & Lifeforms & Habitat & Co. No \\
\hline $\begin{array}{l}\text { Actinodaphne cuneata (Blume) } \\
\text { Boerl. }\end{array}$ & Lauraceae & Medang & Tree & $\mathrm{F}$ & ATAM-22 \\
\hline $\begin{array}{l}\text { Adenia macrophylla (Blume) } \\
\text { Koord. }\end{array}$ & Passifloraceae & & Climber & $\mathrm{F}$ & ATAM-20 \\
\hline Aglaia tomentosa Teijsm. \& Binn. & Meliaceae & & Tree & $\mathrm{F}$ & ATAM-19 \\
\hline Aporosa benthamiana Hook.f. & Phyllantaceae & Kayu asam & Tree & $\mathrm{F}$ & ATAM-35 \\
\hline $\begin{array}{l}\text { Archidendron borneense I.C. } \\
\text { Nielsen }\end{array}$ & Leguminosae & Jengkol hutan & Tree & $\mathrm{F}$ & ATAM-21 \\
\hline $\begin{array}{l}\text { Baccaurea macrophylla } \\
\text { (Müll.Arg.) Müll.Arg. }\end{array}$ & Phyllantaceae & Tampoi & Tree & $\mathrm{F}$ & ATAM-17 \\
\hline Baccaurea polyneura Hook.f. & Phyllantaceae & Jentik & Tree & $\mathrm{F}$ & ATAM-46 \\
\hline $\begin{array}{l}\text { Blumeodendron tokbrai (Blume) } \\
\text { Kurz }\end{array}$ & Euphorbiaceae & Bantas & Tree & $\mathrm{F}$ & ATAM-41 \\
\hline Canarium littorale Blume & Burseraceae & Kenari & Tree & $\mathrm{F}$ & ATAM-45 \\
\hline $\begin{array}{l}\text { Castanopsis costata (Blume) } \\
\text { A.DC }\end{array}$ & Fagaceae & $\begin{array}{l}\text { Berangan } \\
\text { gunung }\end{array}$ & Tree & $\mathrm{F}$ & ATAM-25 \\
\hline Cheilosa montana Blume & Euphorbiaceae & & Tree & $\mathrm{F}$ & ATAM-43 \\
\hline Chisocheton patens Blume & Meliaceae & & Tree & $\mathrm{F}$ & ATAM-24 \\
\hline Diospyros kaki L.f. & Ebenaceae & Kesemek & Tree & $\mathrm{FL}$ & ATAM-07 \\
\hline Durio griffithii (Mast.) Bakh. & Malvaceae & $\begin{array}{l}\text { Durian } \\
\text { enggang }\end{array}$ & Tree & $\mathrm{F}$ & ATAM-32 \\
\hline $\begin{array}{l}\text { Dysoxylum alliaceum (Blume) } \\
\text { Blume }\end{array}$ & Meliaceae & & Tree & $\mathrm{F}$ & ATAM-40 \\
\hline Dysoxylum cyrtobotryum Miq. & Meliaceae & & Tree & $\mathrm{F}$ & ATAM-29 \\
\hline Eleiodoxa conferta (Griff.) Burret. & Arecaceae & Salak Hutan & Palm & $\mathrm{F}$ & ATAM-16 \\
\hline Ficus lepicarpa Blume & Moraceae & Ara & Tree & $\mathrm{F}$ & ATAM-18 \\
\hline Flacourtia rukam Zoll. \&Moritzi & Flacourtiaceae & Rukam & Tree & $\mathrm{FL}$ & ATAM-04 \\
\hline $\begin{array}{l}\text { Garcinia atroviridis Griff. ex } \\
\text { T.Anderson }\end{array}$ & Clusiaceae & $\begin{array}{l}\text { Asam } \\
\text { Gelugur }\end{array}$ & Tree & $\mathrm{FL}$ & ATAM-09 \\
\hline Garcinia nervosa (Miq.) Miq. & Clusiaceae & $\begin{array}{l}\text { Manggis } \\
\text { hutan }\end{array}$ & Tree & $\mathrm{F}$ & ATAM-34 \\
\hline
\end{tabular}




\begin{tabular}{|c|c|c|c|c|c|}
\hline $\begin{array}{l}\text { Garcinia nigrolineata Planch. ex } \\
\text { T.Anderson }\end{array}$ & Clusiaceae & Peralih & Tree & $\mathrm{F}$ & ATAM-28 \\
\hline $\begin{array}{l}\text { Garcinia xanthochymus Hook.f. ex } \\
\text { T.Anderson }\end{array}$ & Clusiaceae & Asam kandis & Tree & $\mathrm{F}$ & ATAM-54 \\
\hline Glycosmis parviflora (Sims) Little & Rutaceae & Urot Merah & Shrub & $\mathrm{F}$ & ATAM-23 \\
\hline Grewia laevigata Vahl & Malvaceae & & Tree & $\mathrm{F}$ & ATAM-49 \\
\hline $\begin{array}{l}\text { Helicia robusta (Roxb.) R.Br. ex } \\
\text { Blume }\end{array}$ & Proteaceae & & Tree & $\mathrm{F}$ & ATAM-31 \\
\hline $\begin{array}{l}\text { Horsfieldia superba (Hook.f. \& } \\
\text { Thomson) Warb. }\end{array}$ & Myristicaceae & & Tree & $\mathrm{F}$ & ATAM-36 \\
\hline Knema laurina (Blume) Warb. & Myristicaceae & Dedarah & Tree & $\mathrm{F}$ & ATAM-38 \\
\hline Lansium domesticum Corrêa & Meliaceae & Langsat & Tree & $\mathrm{FL}$ & ATAM-06 \\
\hline $\begin{array}{l}\text { Lepisanthes fruticosa (Roxb.) } \\
\text { Leenh. }\end{array}$ & Sapindaceae & $\begin{array}{l}\text { Rambutan } \\
\text { biabak }\end{array}$ & Tree & $\mathrm{F}$ & ATAM-37 \\
\hline $\begin{array}{l}\text { Lepisanthes amoena (Haask.) } \\
\text { Leenh. }\end{array}$ & Sapindaceae & & Tree & $\mathrm{F}$ & ATAM-26 \\
\hline $\begin{array}{l}\text { Lithocarpus echinulatus } \\
\text { Soepadmo }\end{array}$ & Fagaceae & & Tree & $\mathrm{F}$ & ATAM-27 \\
\hline $\begin{array}{l}\text { Lithocarpus indutus (Blume) } \\
\text { Rehder }\end{array}$ & Fagaceae & & Tree & $\mathrm{F}$ & ATAM-33 \\
\hline Mangifera foetida Lour. & Anacardiaceae & Macang & Tree & $\mathrm{FL}$ & ATAM-01 \\
\hline Mangifera odorata Griff. & Anacardiaceae & Kuweni & Tree & $\mathrm{FL}$ & ATAM-02 \\
\hline Mangifera laurina Blume & Anacardiaceae & Asam pauh & Tree & $\mathrm{FL}$ & ATAM-03 \\
\hline Microcos latistipulata (Ridl.) Burret & Malvaceae & & Tree & $\mathrm{F}$ & ATAM-47 \\
\hline Momordica balsamina L. & Cucurbitaceae & Pare hutan & Climber & $\mathrm{B}$ & ATAM-13 \\
\hline Nephelium cuspidatum Blume & Sapindaceae & Kapulasan & Tree & $\mathrm{FL}$ & ATAM-05 \\
\hline Nephelium juglandifolium Blume & Sapindaceae & $\begin{array}{l}\text { Rambutan } \\
\text { hutan }\end{array}$ & Tree & $\mathrm{F}$ & ATAM-30 \\
\hline Passiflora edulis Sims. & Passifloraceae & $\begin{array}{c}\text { Markisa } \\
\text { kuning }\end{array}$ & Climber & $\mathrm{B}$ & ATAM-15 \\
\hline Physalis angulata L. & Solanaceae & Ciplukan & Herb & $\mathrm{B}$ & ATAM-14 \\
\hline $\begin{array}{l}\text { Polyspora oblongifolia (Miq.) Orel, } \\
\text { Peter G.Wilson, Curry \& Luu }\end{array}$ & Theaceae & & Tree & $\mathrm{F}$ & ATAM-44 \\
\hline $\begin{array}{l}\text { Pometia pinnata J.R. Forst. \& G. } \\
\text { Forst. }\end{array}$ & Sapindaceae & Matoa hutan & Tree & $\mathrm{F}$ & ATAM-48 \\
\hline Pouteria viridis (Pittier) Cronquist & Sapotaceae & & Tree & $\mathrm{F}$ & ATAM-42 \\
\hline Prunus beccarii (Ridley) Kalkman & Rosaceae & Buah Ceri & Tree & $\mathrm{FL}$ & ATAM-08 \\
\hline Santiria laevigata Blume & Burseraceae & $\begin{array}{l}\text { Kedondong } \\
\text { tunjuk }\end{array}$ & Tree & $\mathrm{F}$ & ATAM-53 \\
\hline Solanum betaceum Cav. & Solanaceae & & Shrub & $\mathrm{F}$ & ATAM-39 \\
\hline $\begin{array}{l}\text { Syzygium garciniifolium (King) } \\
\text { Merr. \& L.M.Perry }\end{array}$ & Myrtaceae & Jambu & Tree & $\mathrm{FL}$ & ATAM-11 \\
\hline $\begin{array}{l}\text { Syzygium polyanthum (Wight) } \\
\text { Walp }\end{array}$ & Myrtaceae & Salam & Tree & $\mathrm{F}$ & ATAM-10 \\
\hline $\begin{array}{l}\text { Syzygium aqueum (Burm. f.) } \\
\text { Alston }\end{array}$ & Myrtaceae & Jambu Air & Tree & $\mathrm{FL}$ & ATAM-12 \\
\hline $\begin{array}{l}\text { Syzygium malaccense (L.) Merr. \& } \\
\text { L.M. Perry }\end{array}$ & Myrtaceae & Jambu Bol & Tree & FL & ATAM-52 \\
\hline Voacanga foetida (Blume) Rolfe & Apocynaceae & $\begin{array}{c}\text { Telur } \\
\text { kambing }\end{array}$ & Tree & $\mathrm{F}$ & ATAM-51 \\
\hline $\begin{array}{l}\text { Xerospermum noronhianum } \\
\text { (Blume) Blume }\end{array}$ & Sapindaceae & & Tree & $\mathrm{F}$ & ATAM-50 \\
\hline
\end{tabular}

Note:

Co. No = collection number

Habitat: $\mathrm{B}=$ Bush; F = Forest; $\mathrm{FL}=$ Farm land 
Table 3. Species with their value addition

\begin{tabular}{|c|c|c|c|c|c|c|c|}
\hline Scientific name & $\begin{array}{l}\text { Plant } \\
\text { part }\end{array}$ & Medicine & Additive & Juice & Pickle & Chutney & Dried \\
\hline Mangifera foetida & Fruit & & & $\checkmark$ & $\checkmark$ & $\checkmark$ & \\
\hline Mangifera odorata & Fruit & & & $\checkmark$ & $\checkmark$ & $\checkmark$ & \\
\hline Mangifera laurina & Fruit & & & $\checkmark$ & $\checkmark$ & $\checkmark$ & \\
\hline Microcos latistipulata & Leaves & $\checkmark$ & & & & & \\
\hline Momordica balsamina & Fruit & $\checkmark$ & & & & & \\
\hline Garcinia atroviridis & Fruit & $\checkmark$ & $\checkmark$ & & & & $\checkmark$ \\
\hline $\begin{array}{l}\text { Garcinia } \\
\text { xanthochymus }\end{array}$ & Fruit & & $\checkmark$ & & & & \\
\hline Syzygium aqueum & Fruit & & & & $\checkmark$ & & \\
\hline $\begin{array}{l}\text { Syzygium } \\
\text { garciniifolium }\end{array}$ & Fruit & & & & $\checkmark$ & & \\
\hline Syzygium malaccense & Fruit & & & & $\checkmark$ & & \\
\hline Santiria laevigata & Leave & $\checkmark$ & & & & & \\
\hline $\begin{array}{l}\text { Baccaurea } \\
\text { macrophylla }\end{array}$ & Leave & $\checkmark$ & & & & & \\
\hline Physalis angulata & Leave & $\checkmark$ & & & & & \\
\hline Syzygium polyanthum & Leave & & $\checkmark$ & & & & \\
\hline Voacanga foetida & Leave & $\checkmark$ & & & & & \\
\hline
\end{tabular}

Table 4. Wild edible fruit plants commercialized in the study area

\begin{tabular}{lccc}
\hline \multirow{2}{*}{ Scientific name } & Trade part & \multicolumn{2}{c}{ Marketing (n=450) } \\
\cline { 3 - 4 } & & $\begin{array}{c}\text { Mean quantity per } \\
\text { respondent (kg) }\end{array}$ & $\begin{array}{c}\text { Market Price } \\
\text { (IDR/kg) }\end{array}$ \\
\hline Baccaurea macrophylla & Fruit & $50 \pm 1.05$ & $8,000 \pm 408.24$ \\
Baccaurea polyneura & Fruit & $25 \pm 2.75$ & $6,000 \pm 712.19$ \\
Diospyros kaki & Fruit & $60 \pm 4.21$ & $12,000 \pm 1,290.99$ \\
Flacourtia rukam & Fruit & $10 \pm 1.94$ & $5,000 \pm 308.11$ \\
Garcinia atroviridis & Fruit & $50 \pm 1.53$ & $12,000 \pm 1,312.33$ \\
Garcinia xanthochymus & Fruit & $50 \pm 1.93$ & $5,000 \pm 406.25$ \\
Lansium domesticum & Fruit & $200 \pm 10.54$ & $15,000 \pm 471.41$ \\
Mangifera foetida & Fruit & $200 \pm 12.24$ & $20,000 \pm 2,818.59$ \\
Mangifera odorata & Fruit & $160 \pm 2.82$ & $20,000 \pm 2,581.57$ \\
Mangifera laurina & Fruit & $50 \pm 1.08$ & $7,000 \pm 1,490.71$ \\
Nephelium cuspidatum & Fruit & $40 \pm 2.10$ & $7,000 \pm 1,220.19$ \\
Passiflora edulis & Fruit & $50 \pm 1.23$ & $10,000 \pm 1,228.29$ \\
Pometia pinnata & Fruit & $40 \pm 2.16$ & $8,000 \pm 302.18$ \\
Syzygium malaccense & Fruit & $100 \pm 12.37$ & $8,000 \pm 430.21$ \\
Syzygium aqueum & Fruit & $100 \pm 13.65$ & $8,000 \pm 204.56$ \\
\hline
\end{tabular}

* Mean \pm Standard deviation

Note: 1 USD = 14,500 IDR in August 12, 2018 from id.exchange-rates.org 


\section{Discussion}

A total of 54 wild edible fruit species belonging to 41 genera and 27 families were identified in the study areas. Most WEFs were found to grow wild in the forest, while several WEFs such as Kuwini (M. odorata) and Mancang ( $M$. foetida) have been found to have a natural occurrence in the farmlands. The harvesting of WEFs is carried out by men compared to women. Men make more frequent visits to the forest to gather fuelwood and hunt animals, which explains this. This study differs from the report by Mahapatra \& Panda (2012) from the state of Orissa, India, which gathers most of the wild fruits of women compared to men. Differences between genders in the collection of WEFs are influenced by different objectives, perceptions, interests, and access to resources between communities. In this study area, men collect WEFs while also collecting fuelwood or hunting animals. A similar method of the collection was reported in localities of Peru (Phillips \& Gentry 1993), and in Botswana (Legwaila et al. 2011). The intensity of use of WEFs has been reported on the characteristics of the plants used and the livelihood of the people (Shrestha \& Dhillion 2006; Suresh et al. 2014). WEFs have been associated with the traditions and culture of local peoples (Bussmann et al. 2006; Medley \& Kalibo 2007; Addis et al. 2013).

The high diversity of WEFs in the study area shows that local people possess traditional knowledge about local plant species that provide food. Local people tend to take advantage of a variety of plants that are more accessible or abundant locally (Srivastava 1988). The number of species recorded in this study is comparable to the 56 wild edible fruit species (26 families) reported from the Orissa state of India (Mahapatra \& Panda 2012), and 56 species (24 families) in South Aceh, Indonesia (Suwardi et al. 2020b). However, it is also higher than the 44 species reported from the West Aceh, Indonesia (Suwardi et al. 2019b), 38 species from the Gayo Highlands of Indonesia (Navia et al. 2020), 33 species from Rupandehi district, Nepal (Acharya \& Acharya 2010), 27 species from Shorobe, Northern Botswana (Neudeck et al. 2012), 12 species from Uttara Kannada district of Karnataka (Hebbar et al. 2010), and 11 species reported from Dera Ismail Khan district of northwestern Pakistan (Marwat et al. 2011). This variance in the diversity of WEFs has been attributed to disparities in culture and location (Arora \& Anjula 1996).

During the discussions, the respondents stated that $M$. foetida and $M$. odorata are the most preferred fruit species because of their sweet taste and fragrant smell. This is similar to that report of Navia et al. (2020) that M. foetida and M. odorata were the most popular and preferred fruits by the community in Central Aceh, Indonesia. The taste was an important criterion for the preference for fruit (Sujarwo et al. 2015; Navia et al. 2020). Most WEFs have sweet or a slightly sour taste and are preferred by local people in the study area which is comparable to cultivated fruits. WEFs offer various essential nutrients to maintain human health. For example, $M$. foetida fruit is reported to have a high nutritional (Tee et al. 1997) and antioxidant content (Tyug et al. 2010), and is essential to supplement nutrients in the community. In addition, G. atroviridis fruits contain potassium hydroxycitrate that helps to reduce cholesterol (Jena et al. 2002), and may be used in the treatment of obesity (Mattes \& Bornmann 2000; Tisdale et al. 2003; Preuss et al. 2004; Hamidon et al. 2017).

Most WEFs are eaten fresh by the local community in the study area, but several species have additional value. M. odorata and M. laurina are used for juice, pickles, and chutneys, while $M$. foetida, $S$. aqueum, S. garciniifolium, and $S$. malaccense are used for pickle. This study is in line with the report of Tyug et al. (2010) from Malaysia, where M. foetida is used as pickles. G. atroviridis has traditionally been used in food preparation and cooking, mainly to make food more filling. Clouatre \& Rosenbaum (1994) reported that $G$. atroviridis contains HCA (Hydroxy citric acid) and is traditionally used to make meals more filling. In addition, $G$. atroviridis fruit is cut into thin slabs, dehydrated by sun-drying, and stored for a certain period before being used as an ingredient or sold on the market. Its preparation method is similar to that reported by Rittirut \& Siripatana (2006) from Thailand, where the community often dried $G$. atroviridis thin slabs by sun-drying in the air and kept them before entering the juice production process.

The respondents state that the value addition of WEFs may increase the price of the product by three to four times. For example, $M$. foetida in raw fruit form is sold in traditional markets at IDR $20,000 \mathrm{~kg}^{-1}$, whereas, it may increase to IDR $40,000 \mathrm{~kg}^{-1}$ if processed into mango juice. Diversification of products is expected to increase profits, which are a good source of income for the community. The diversification of products of several wild fruits has already been adopted in other areas and reported as highly remunerative (Maikhuri et al. 1998). The fruit of $M$. balsamina was used as traditional medicine for the treatment of diarrhea by people in the Bandar Pusaka sub-district. Aqueous extract from $M$. balsamina showed an antidiarrheal effect (Otimenyin et al. 2008) and is being used in Nigeria for the management of diarrhea (Thakur et al. 2009). The leaves of $B$. macrophylla are used in the treatment of ringworm, while leaves of $S$. laevigata were used in the treatment of diarrhea. In addition, $G$. atroviridis is 
traditionally used to treat cough and stomach pains. This fruit has been reported to have bioactive compounds such as saponins, phenolic, flavonoids, and anthraquinone glycosides (Roslan et al. 2019). It is traditionally used by the communities in Riau, Indonesia for pain in the ears, dandruff, cough, and stomach (Grosvenor et al. 1995; Alsarhan et al. 2014).

In the Aceh Tamiang region, all commerce and trade activities primarily are conducted in the local market. The frequency of the market days and the demand for goods depends on the socio-economic conditions of the people in the area. These markets serve as collection points for local products as well as for the distribution of goods. A variety of items are sold in this market. Some of the common products are fruits, vegetables, grains, agricultural produce, animals, and their by-products. In the study area, women and children usually sell WEFs in limited quantities door to door or on the roadside around villages. Similar methods have been reported from Gweta village, Bostwana (Badimo et al. 2015), in East Kalimantan, Indonesia (Koizumi 2005), and in Nepal (Shrestha \& Dhillion 2006). However, when the quantity of WEFs is harvested in large quantities, they are sold in traditional local markets. The sale of WEFs provides income used to meet several family needs such as buying food or paying school fees. Sale of WEFs can provide $34.41 \%$ of the total annual family income in the study area. This contribution of WEFs is lower than reported by Pardede et al. (2018) from Riau Province, Indonesia where they accounted for $38 \%$ of the total annual family income, and in Central Aceh, Indonesia (43\%) (Navia et al. 2020).

WEFs in Aceh Tamiang region offers diverse benefits to the communities. These plants grow abundantly in the wild and have economic potential as a source of household income. However, efforts should be made to domesticate or cultivate them in the communities' farmlands outside the GLNP area. Training and technology transfer must be provided to local communities to support the cultivation of WEFs. These activities must be supported by the Indonesian government through the Aceh Tamiang District Agriculture Office to emphasize the domesticating of WEFs in providing economic values. Intensive cultivation of WEFs may also reduce the dependence of communities on the GLNP. As a result, in addition to providing economic benefits, the domestication of WEFs is also a conservation strategy for WEFs in the GLNP. The marketing of WEFs continues to be a challenge, especially for local people who are engaged in this business. The promotion and marketing efforts of WEFs must be carried out intensively. Fortunately, the Aceh Tamiang region is an attractive tourist destination for both natural and cultural tourism, visited by millions of tourists every year. The Indonesian government through the Aceh Tamiang District Tourism, Youth, and Sports Office must be involved in promoting WEFs. Intensively promoting and marketing WEFs will have more positive impact on the economic growth of the people in the Aceh Tamiang region.

\section{Conclusions and recommendations}

A total of 54 WEFs belonging to 27 families and 41 genera were found in the study area. Thirty-nine (72.22 \%) species were found growing in forests, 12 $(22.22 \%)$ species in farmland, and 3 (5.56\%) species occur in the bush. Several species have economic value including Baccaurea macrophylla, Baccaurea polyneura, Diospyros kaki, Flacourtia rukam, Garcinia atroviridis, Garcinia xanthochymus, Lansium domesticum, Mangifera foetida, Mangifera odorata, Mangifera laurina, Nephelium cuspidatum, Passiflora edulis, Pometia pinnata, Syzygium malaccense, and Syzygium aqueum. The sale of WEFs contributed approximately $34.31 \%$ to the total annual household income, and are thus relevant to household food security. Policies and legislations developed by involving all stakeholders are required to ensure the cultivation, management, sustainable use, and promotion of WEFs in order to encourage the economic growth of the rural community in the Aceh Tamiang region.

\section{Declarations}

List of abbreviations: WEFs = Wild edible fruit species; GLNP = Gunung Leuser National Park; a.s.I = above sea level.

Availability of data and materials: Data will be available from the corresponding author on special request.

\section{Ethical approval and consent to participate:}

Permission was taken from the subdistrict heads of Tenggulun, Tamiang Hulu, and Bandar Pusaka prior to data collection. Oral informed consent was obtained from all informants.

Consent for publication: Not applicable.

Conflict of interests: The authors declare no competing interests.

Funding: The study received funding from the Ministry of Research, Technology, and Higher Education, the Republic of Indonesia.

Authors' contributions: ABS and TH carried out fieldwork, data analysis, and drafted the manuscript. ZIN configured the research project. The work was supervised by S and EM. All authors read, reviewed, and approved the final version of the manuscript. 


\section{Acknowledgments}

We are grateful to the Directorate General of the Ministry of Research, Technology, and Higher Education, the Republic of Indonesia for the Collaborative Research Grant we received. We would also like to thank all local people who assisted and cooperated in this study.

\section{Literature cited}

Acharya KP, Acharya R. 2010. Eating from the wild: Indigenous knowledge on wild edible plants in Paroha VDC of Rupandehi district, Central Nepal. International Journal of Social Forestry 3: 28-48

Addis G, Asfaw Z, Woldu Z. 2013. Ethnobotany of Wild and Semi-wild edible plants of Konso ethnic community, South Ethiopia. Ethnobotany Research \& Applications 11:121-141

Ahenkan A, Boon E. 2011. Non-timber forest products (NTFPs): Clearing the confusion in semantics. Journal of Human Ecology 33(1): 1-9

Alsarhan A, Sultana N, Al-Khatib A, Kadir MRA. 2014. Review on some malaysian traditional medicinal plants with therapeutic properties. Journal of Basic \& Applied Sciences 10: 149-159

Arora RK, Anjula P. 1996. Wild edible plants of India: diversity conservation and use. ICAR New Delhi, India

Badimo D, Joyce Lepetu J, Teketay D. 2015. Utilization of edible wild plants and their contribution to household income in Gweta Village, central Botswana. African Journal of Food Science and Technology 6(7): 220-228

Bagra G, De LC, Singh VB. 2006. Collection and evaluation of some indigenous lesser known fruits of Arunachal Pradesh. Horticulture for Sustainable Income and Environmental Protection 1: 224231

Beluhan S, Ranogajec A. 2010. Chemical composition and non-volatile components of Crotial wild edible mushrooms. Food Chem 124:1076-82.

Biswas SC, Majumdar M, Das S, Misra TK. 2018. Diversity of wild edible minor fruits used by the ethnic communities of Tripura, India. Indian Journal of Traditional Knowledge 17(2): 282-28

Bussmann RW, Gilbreath GG, Solio J, Lutura M, Lutuluo R, Kunguru K, Wood N, Mathenge SG. 2006. Plant use of the Maasai of Sekenani Valley, Maasai Mara, Kenya. Journal of Ethnobiology and Ethnomedicine 2: 22

Bvenura C, Sivakumar D. 2007. The role of wild fruits and vegetables in delivering a balanced and healthy diet. Food Research International 99: 15-30

Clouatre D, Rosenbaum ME. 1994. The diet and health benefits of HCA (hydroxycitric acid). Keats Publishing, New Canaan, CT
Deb CR, Jamir NS, Ozukum S. 2013. A study on the survey and documentation of Underutilized crops of three district of Nagaland, India. Global Journal of Bioscience 2: 67-70

Diamond J. 2002. Evolution, consequences and future of plant and animal domestication. Nature 418:700-707

Grosvenor PW, Gothard PK, McWilliam NC, Supriono AG, Gay DO. 1995. Medicinal plants from Riau province, Sumatra, Indonesia. Part 1: uses. Journal of Ethnopharmacology 45: 75-95

Hamidon H, Susanti D, Taher M, Zakaria ZA. 2017. Garcinia atroviridis - A review on phytochemicals and pharmacological properties. Marmara Pharmaceutical Journal 21: 38-47

Hebbar SS, Hegde G, Hegde GR. 2010. Less known wild edible fruits and seeds of Uttar Kannada district of Karnataka. Indian Forester 136: 1218-1222

Jena BS, Jayaprakasha GK, Singh RP, Sakariah KK. 2002. Chemistry and biochemistry of (-)hydroxycitric acid from Garcinia. J Agric Food Chem 50: $10-22$

Khruomo N, Deb CR. 2018. Indigenous Wild edible fruits: sustainable resources for food, medicine and income generation - A study from Nagaland, India. Journal of Experimental Biology and Agricultural Sciences 6(2): 405-413

Koizumi, M. 2005. Ethnobotany of the Penan Benalui of East Kalimantan, Indonesia: Difference of ethnobotanical knowledge among villagers of long Belaka. African Study Monographs. Supplement 29: 53-60

Leonti M, Nebel S, Rivera D, Heinrich M. 2006. Wild Gathered Food Plants in the European Mediterranean: A Comparative Analysis. Economic Botany 60(2): 130-142

Legwaila GM, Mojeremane W, Madisa ME,Mmolotsi RM, Rampart M. 2011. Potential of traditional food plants in rural household food security in Botswana. Journal of Horticulture and Forestry 3: 171-177

Lulekal E, Asfaw Z, Kelbessa E, Damme PV. 2011. Wild edible plants in Ethiopia: $A$ review on their potential to combat food insecurity. Afrika Focus 24(2): 71-121

Mabaya E, Jackson J, Ruethling G, Carter CM, Castle J. 2014. Wild fruits of Africa: Commercializing natural products to improve rural livelihoods in southern Africa. Int Food Agribus Man 17: 69-74

Maghembe JA, Simons AJ, Kwesiga F, Rarieya M. 1998. Selecting indigenous fruit trees for domestication in southern Africa: Priority setting with farmers in Malawi, Tanzania, Zambia and Zimbabwe. International Centre for Research in Agroforestry, Nairobi, Kenya 
Mahapatra AK, Panda, PC. 2012. Wild edible fruit diversity and its significance in the livelihood of indigenous tribals: Evidence from eastern India. Food Sec. 4: 219-234

Maikhuri RK, Semwal RL, Singh A, Nautiyal MC. 1994. Wild fruits as a contribution to sustainable rural development: A case study from the Garhwal Himalaya. International Journal of Sustainable Development World Ecology 1: 56-68.

Marwat SK, Rehman U, Usmaan K, Khakwani AA, Ghulam S, Anwar N, Sadiq M, Khan SJ. 2011. Medico-ethnobotanical studies of wild edible fruits plants species for the flora of north western Pakistan (D.I. Khan District). Journal of Medical Plant Research 5: 3679-3686

Maske M, Mungole A, Kamble R, Chaturvedi A, Chaturvedi A. 2011. Impact of non-timber forest produces (NTFPs) on rural tribes' economy in Gondia district of Maharashtra, India. Achieves of Applied Science Research 3(30): 109-114.

Mattes RD, Bornmann L. 2000. Effects of (-)hydroxycitric acid on appetite variables. Physiology \& Behaviour 71: 87-9.

Medley KE, Kalibo HW. 2007. Ethnobotanical survey of 'wild' woody plant resources at mount Kasigau, Kenya. Journal of East African Natural History 96: 149-186

Mwema CM, Mutai BK, Lagat JK, Kibet LK, Maina MC. 2012. Contribution of selected indigenous fruits on household income and food security in Mwingi, Kenya. Curr Res J Soc Sci 4 (6): 425-430

Navia ZI, Chikmawati T. 2015. Durio tanjungpurensis (Malvaceae), a new species and its one new variety from West Kalimantan, Indonesia. Bangladesh J. Bot. 44 (3): 429-436.

Navia ZI, Suwardi AB, Harmawan T, Syamsuardi, Mukhtar E. 2020. The diversity and contribution of indigenous edible fruit plants to the rural community in the Gayo Highlands, Indonesia. Journal of Agriculture and Rural Development in the Tropics and Subtropics 121(1): 89-98

Neudeck L, Avelino L, Bareetseng P, Ngwenya BN, Teketay D, Motsholapheko MR. 2012. The contribution of edible wild plants to food security, dietary diversity and income of households in Shorobe village, Northern Botswana. Ethnobotany Research \& Applications 10:449-462

$\mathrm{Ng}$ FSP. 1995. Tree Flora of Malaya a manual for foresters. Vol 3 \& 4. Longman Malaysia, Kuala Lumpur

Ohiokpehai O. 2003. Promoting the nutritional goodness of traditional food products. Pak J Nutrition 2: $267-270$

Oryema C, Oryem-Origa H, Nanna R. 2013. Edible wild fruit species of Gulu District, Uganda.
International Journal of Biology and Biological Sciences 2(4): 068-082

Otimenyin OS, Uguru OM, Akanbi BE. 2008. Antidiarrhea effect of aqueous extracts of Momordica balsamina and Stachytarpheta indica in Rats. J. Nat. Prod 1: 36-45

Pardede KN, Sribudiani E, Yoza D. 2018. The contribution of non timber forest products toward community revenue around Bukit Rimbang Bukit Baling Wildlife Sanctuary. Jurnal IImu Kehutanan Faperta UR 2(2): 17-25

Phillips O, Gentry AH. 1993. The useful plants of Tambopata, Peru: I. Statistical hypothesis tests with a new quantitative technique. Economic Botany 47:15-32

Preuss H, Bagchi D, Bagchi M, Rao CVS, Satyanarayana S, Dey DK. 2004. Efficacy of a novel, natural extract of (-)-hydroxycitric acid (HCA-SX) and a combination of HCA-SX, niacin-bound chromium and Gynnemia sylvestre extract in weight management in human volunteers: A pilot study. Nutrition Research 24: 45-58.

Rittirut W, Siripatana C. 2006. Drying characteristics of Garcinia atroviridis. Walailak J Sci \& Tech 3(1): 1332

Roslan NSA, Zareen S, Zamri N, Akhtar MN. 2019. Preliminary phytochemical screening, GC-MS profiling and in vitro evaluation of biological activities of Garcinia atroviridis root extracts. International Journal of Advanced Research 7(1): 53-61

Saka JDK, Msonthi JD. 1994. Nutritional value of edible fruits of indigenous wild trees in Malawi. Forest Ecology and Management 64: 245-24

Salih-Kamal EM, Ali AH. 2014. Wild food trees in Eastern Nuba Mountains, Sudan: Use, diversity, and threatening factors. Journal of Agriculture and Rural Development in the Tropics and Subtropics 115 (1): 1-7

Shava S. 2005. Research on indigenous knowledge and its application: A case of wild food plants of Zimbabwe. Southern African Journal of the Environment Education 22: 73-86.

Shrestha PM, Dhillion SS. 2006. Diversity and traditional knowledge concerning indigenous food species in a locally managed forest in Nepal. Agroforestry Systems 66: 55-63

Somnasang P, Moreno-Black G. 2000. Knowing, gathering and eating: knowledge and attribute about wild food in an Asian village in North-eastern Thailand. Journal of Ethnobiology 20: 197.

Srivastava TN. 1988. Wild edible plants of Jammu and Kashmir state - an ethnobotanical study. Anc Sci Life 7(3-4): 201-6

Sujarwo W, Arinasa IBK, Caneva G, Guarrera PM. 2015. Traditional knowledge of wild and semi-wild 
edible plants used in Bali (Indonesia) to maintain biological and cultural diversity. Plant Biosystems 16.

Sundriyal M, Sundriyal RC, Sharma E, Purohit AN. 1998. Wild edibles and other useful plants of Sikkim Himalayas, India. Oecologia Montana 7: 43-54

Suresh CP, Bhutia KD, Shukla G, Pradhan K, Chakravarty S. 2014. Wild edible tree fruits of Sikkim Himalayas. Journal of Tree Sciences 33: 43-48

Suwardi AB, Indriaty, Navia ZI. 2018. Nutritional evaluation of some wild edible tuberous plants as an alternative foods. Innovare Journal of Food Sciences 6(2): 9-12

Suwardi AB, Navia ZI, Harmawan T, Syamsuardi, Mukhtar E. 2019a. Sensory evaluation of mangoes grown in Aceh Tamiang district, Aceh, Indonesia. Advances in Ecological and Environmental Research 4(1): 79-85

Suwardi AB, Navia ZI, Harmawan T, Syamsuardi, Mukhtar E. 2019b. The diversity of wild edible fruit plants and traditional knowledge in West Aceh region, Indonesia. Journal of Medicinal Plants 7 (4): 285-290

Suwardi AB, Navia ZI, Harmawan T, Nuraini, Syamsuardi, Mukhtar E. 2020a. Ethnobotany, nutritional composition and sensory evaluation of Garcinia from Aceh, Indonesia. Materials Science and Engineering 725 (1): 012064

Suwardi AB, Navia ZI, Harmawan T, Syamsuardi, Mukhtar E. 2020b. Ethnobotany and conservation of indigenous edible fruit plants in South Aceh, Indonesia. Biodiversitas 21(5): 1850-1860

Tee ES, Ismail MN, Nasir MA, Khatijah I. 1997. Nutrient composition of Malaysian foods. Institute Medical for Research, Kuala Lumpur, Malaysia

Thakur GS, Bag M, Sanodiya BS, Bhadauriya P, Debnath M, Prasad GBKS, Bisen PS. 2009. Momordica balsamina: A Medicinal and Neutraceutical Plant for Health Care Management. Current Pharmaceutical Biotechnology 10: 667-682

The Central Bureau of Statistics of Aceh Tamiang Regency. 2019. Aceh Tamiang Regency in figure 2019. The Central Bureau of Statistics of Aceh Tengah Regency, Aceh Tamiang Regency, Indonesia

Tisdale EJ, Kochman DA, Theodorakis EA. 2003. Total syntesis of atroviridin. Tetrahedon Lett. 44(16): 3281-3284

Tyug TS, Johar MH, Ismail A. 2010. Antioxidant properties of fresh, powder, and fiber products of Mango (Mangifera foetida) fruit. International Journal of Food Properties 13 (4): 682-691

Verheij EWM, Coronel RE. 1992. Plant resources of South-East Asia No 2 Edible Fruits and Nuts. Pudoc Scientific Publishers, Wageningen, Netherlands
WCS. 2019. Monitoring forest cover changes in The Gunung Leuser National Park and surrounding between 2000-2017. Balai Besar Taman Nasional Gunung Leuser \& Wildlife Conservation Society Indonesia Program, Medan, Indonesia

Whitmore TC. 1983. Tree Flora of Malaya A Manual for Foresters. Vol 1 \& 2. Longman Malaysia, Kuala Lumpur, Malaysia

Wiratno, Indriyo D, Syarifudin A, Kartikasari A. 2004. Look in the cracked mirror. Conservation reflections and implications for management of National Parks. Second Edition. Forest Press, The Gibbon Foundation Indonesia, Ministry of Forestry, PILINGO Movement, Indonesia 
Appendix 1. Survey Questionnaire for Identification of indigenous edible fruit plants to promote diversification and food security in Aceh Province, Indonesia

No. of Respondent:

Date:

PART 1 -BACKGROUND INFORMATION

Name of Respondent:

Sex:

Age:

Marital status:

Tribe:

Address:

\section{PART 2 -COLLECTION AND HARVESTINGOF WILD EDIBLE FRUIT PLANTS}

1. Are you familiar with the wild edible fruit plants?

2. Where do usually go to find wild edible fruit plants?

3. Have you ever harvested any wild edible fruit plants?

4. How often do you usually harvest wild edible fruit plants in a year?

5. Fill in the species and quantity of wild edible fruit plants that you are harvesting this year!

\begin{tabular}{|l|l|l|}
\hline No. & Common name & Quantity (Kg) \\
\hline & & \\
\hline & & \\
\hline
\end{tabular}

6. How do you consume these wild edible fruit plants? (to be eaten raw, processed, etc.)?

7. How do you use wild edible fruit plants? (for sale, self-consumption, etc.)

\section{PART 3 -TRADE OF WILD EDIBLE FRUIT PLANTS}

1. Have you ever sold any wild edible fruit plants?

2. Where do you usually sell wild edible fruit plants?

3 .Fill in the species, traded part, quantity and market price of wild edible fruit plants that you're selling this year!

\begin{tabular}{|l|l|l|l|l|}
\hline No. & Common name & Traded part & Quantity (Kg) & Market Price (Rp) \\
\hline & & & & \\
\hline & & & & \\
\hline
\end{tabular}

